\title{
Cadmium pollution from phosphate fertilizers in arable soils and crops: an overview
}

\author{
Andrea Giovanna NIÑO-SAVALA (ه) ${ }^{1}$, Zhong ZHUANG ${ }^{2}$, Xin MA ${ }^{2}$, Andreas FANGMEIER ${ }^{1}$, Huafen LI $^{2}$, \\ Aohan TANG ${ }^{2}$, Xuejun LIU ${ }^{2}$
}

1 Institute of Landscape and Plant Ecology, University of Hohenheim, 70599 Stuttgart, Germany

2 College of Resources and Environmental Sciences, China Agricultural University, Beijing 100193, China

\begin{abstract}
The application of mineral and organic phosphorus fertilizers to arable land has greatly increased crop yield to meet the world food demand. On the other hand, impurities in these fertilizers, such as heavy metals, are being added to agricultural soils, resulting both from the raw materials themselves and the processes used to obtain the final product. Cadmium, a non-essential and toxic heavy metal, has been found in relatively high amounts in common P fertilizers obtained from sediments. This metal poses a high risk for soil fertility, crop cultivation, and plants in general. Furthermore, human health might be compromised by the cadmium concentrations in agricultural and livestock products, due to the bioaccumulation effect in the food web. The accumulation in the different matrixes is the result of the high mobility and flexible availability of this harmful metal. This review summarizes risks to human health, the factors influencing cadmium movement in soils and crop uptake, as well as common plant responses to its toxicity. In addition, it summarizes cadmium balances in soils, trends, long-term experiments, and further studies. Cadmium inputs and outputs in arable soil, together with their calculated concentrations, are compared between two different regions: the European countries (in particular Germany) and China. The comparison appears useful because of the different proportions in the inputs and outputs of cadmium, and the diverse geographical, environmental and social factors. Moreover, these variables and their influences on cadmium contamination improve the understanding of the pollution from phosphate fertilizers and will help to establish future mitigation policies.
\end{abstract}

Keywords soil pollution, arable land, crop production, cadmium balance, $\mathrm{P}$ fertilizer, cadmium toxicity

Received March 26, 2019; accepted June 10, 2019

Correspondence: andreag_nino@uni-hohenheim.de

\section{Introduction}

Phosphorus is a scarce essential element for plant, animal and human life. It forms part of the sugar phosphates in the structures of DNA and RNA, as well as component of other biomolecules including ATP and phospholipids ${ }^{[1]}$. Thus, the element is involved in virtually all metabolic processes. The availability of this scarce macronutrient is the product of its cycle and its pools. The soil pools include $\mathrm{P}$ in solution (available for plants in organic or orthophosphate form), active (depending on soil $\mathrm{pH}$ bound as $\mathrm{Ca}$-, $\mathrm{Fe}-$, Al-phosphate, metal hydroxides or as organic phosphate, but potentially mobilized by biogenic activity) and fixed (in deposits or sediments) ${ }^{[2]}$.

Due to its deficiency in many soils and the human need for higher crop yields, mineral phosphorus fertilizers are produced via the treatment of phosphate rock (PR) from sedimentary or igneous origin ${ }^{[3,4]}$. The final products of the process include phosphoric acid, superphosphate (SP) and triple superphosphate (TSP) ${ }^{[4]}$. Other common P fertilizers include monoammonium (MAP) and diammonium (DAP) phosphate, the result of nitrogen addition in ammonium form to phosphoric acid ${ }^{[5]}$.

The production and consumption of $\mathrm{P}$ fertilizers have been rising and will rise further to meet the food demand of the increasing global population (Table 1$)^{[9]}$. Phosphorus slowly accumulates in $\mathrm{P}$ mineral deposits, which are renewed over a time-scale of thousands to millions of years. The intense mining activity for agricultural purposes is rapidly decreasing these high-quality rock phosphate deposits, leading to a probable scarcity or depletion in the next 50-100 years, although other studies claim that the actual reserves will last for 400 years or more ${ }^{[1,10,11]}$. According to the most recent survey by the Geological Survey in $2018^{[12]}$, the world P reserves will last around 260 years, taking into account the phosphate mine production $\left(270 \mathrm{kt} \cdot \mathrm{yr}^{-1}\right)$ and reserves $(70000 \mathrm{kt})$. 
Beside potentially exhausting $\mathrm{P}$ stocks, another problem is the presence of toxic heavy metals in the fertilizer input added to otherwise uncontaminated arable soils ${ }^{[9,13-15]}$. These non-essential heavy metals, including cadmium, may disturb human, animal and plant life even at low concentrations $^{[9,16,17]}$.

\section{Cadmium in the environment and its health risks}

\subsection{Health risks by cadmium consumption}

Cadmium is known as a toxic heavy metal with high mobility and hazardous effects for human life and the environment (Fig. 1 ${ }^{[16-20]}$. For human health, the tolerable weekly intake given by the World Health Organization is $7.00 \mu \mathrm{g} \cdot \mathrm{kg}^{-1}$ bodyweight ${ }^{[20-22]}$. However, an intake above $75.00 \mu \mathrm{g} \cdot \mathrm{d}^{-1} \mathrm{Cd}$ by an average adult person is considered a hazardous consumption, since cadmium has a half-life about 20 years in the human body ${ }^{[17,22]}$.

Cadmium can cause damage to DNA and disturbances to enzyme activities. As a consequence, cadmium can trigger failure or cancer in different organ systems, including the reproductive system, muscles, bones (by demineralization and $\mathrm{Ca}$ replacement), heart, lungs, liver, and kidneys. The kidneys accumulate most of the cadmium and it often binds to proteins, due to its affinity for sulfhydryl and phosphate groups ${ }^{[17,18,20,23,24]}$.

\subsection{Cadmium in soil}

In general, cadmium concentrations in surface soils range from 0.06 to $1.10 \mathrm{mg} \cdot \mathrm{kg}^{-1}$ with an average of $0.41 \mathrm{mg} \cdot \mathrm{kg}^{-1[17]}$. The cadmium concentrations in arable land in Germany are on average $0.31 \mathrm{mg} \cdot \mathrm{kg}^{-1}(0.30$ $\left.1.20 \mathrm{mg} \cdot \mathrm{kg}^{-1}\right)^{[25,26]}$, with concentrations varying with the soil type. Arable soils in China contain an average concentration of $0.27 \mathrm{mg} \cdot \mathrm{kg}^{-1} \mathrm{Cd}$, with higher amounts in soils near areas of mining and industrial activity, where the values can reach $150.00 \mathrm{mg} \cdot \mathrm{kg}^{-1[25]}$.

The bioavailability of heavy metals (including $\mathrm{Cd}$ ) via plant roots depends on various factors: abiotic factors include the metal concentration in soil and the physicochemical characteristics $(\mathrm{pH}$, clay content, salinity, humidity, mineral, and organic matter); and biotic factors including the presence of metal-releasing microorganisms and the substances (enzymes, organic acids and hydrogen ions) released into the rhizosphere ${ }^{[20,26-28]}$.

Due to its high mobility, cadmium can be transferred from soil to plants including crops, thereby increasing the risk of bioaccumulation along the food chain ${ }^{[23]}$. Cadmium solubility and bioavailability in soils is strongly dependent on $\mathrm{pH}^{[17,20,26,29-33]}$. Lower mobility is observed when the $\mathrm{pH}$ is above 7.5, and a higher availability under lower $\mathrm{pH}$ conditions. The critical $\mathrm{pH}$ range is between 4.0 and 4.5 where a decrease of $0.2 \mathrm{pH}$ units can cause up to five times higher mobilization and bioavailability ${ }^{[16,30]}$. However, cadmium uptake by plants can be reduced or suppressed

Table 1 Phosphate rock production and reserves (kt; data from US Geological Survey ${ }^{[6,7]}$ ), and production and demand of P fertilizers (kt; data from International Fertilizer Industry Association ${ }^{[8]}$ )

\begin{tabular}{|c|c|c|c|c|c|c|}
\hline \multirow{2}{*}{ Year } & \multirow{2}{*}{ Country } & \multicolumn{3}{|c|}{ Phosphate Rock USGS 2019} & \multicolumn{2}{|c|}{ IFAData 2019} \\
\hline & & Production & Reserves $^{\mathrm{a}}$ & $\mathrm{P}_{2} \mathrm{O}_{5}$ content & Production $\left(\mathrm{P}_{2} \mathrm{O}_{5}\right)$ & Demand $\left(\mathrm{P}_{2} \mathrm{O}_{5}\right)$ \\
\hline \multirow[t]{5}{*}{2010} & All countries & 181000 & 65000000 & 56000 & 42532 & 41663 \\
\hline & China & 68000 & 3700000 & 20400 & 15998 & 13092 \\
\hline & Germany & - & - & - & 3 & 286 \\
\hline & Morocco and Western Sahara & 26600 & 50000000 & 8800 & 1875 & 191 \\
\hline & United States & 25800 & 1400000 & 7400 & 6297 & 3890 \\
\hline \multirow[t]{5}{*}{2015} & All countries & 223000 & 69000000 & 73900 & 44139 & 43912 \\
\hline & China & 120000 & 3700000 & 36000 & 17224 & 12111 \\
\hline & Germany & - & - & - & 25 & 225 \\
\hline & Morocco and Western Sahara & 30000 & 50000000 & 9100 & 2169 & 221 \\
\hline & United States & 27600 & 1100000 & 7710 & 5257 & 4302 \\
\hline \multirow[t]{5}{*}{2018} & All countries & 270000 & 70000000 & - & - & - \\
\hline & China & 140000 & 3200000 & - & - & - \\
\hline & Germany & - & - & - & - & - \\
\hline & Morocco and Western Sahara & 33000 & 50000000 & - & - & - \\
\hline & United States & 27000 & 1000000 & - & - & - \\
\hline
\end{tabular}

Note: ${ }^{a}$ The estimated reserves correspond to the survey done the year after 2011, 2016 and 2019. 


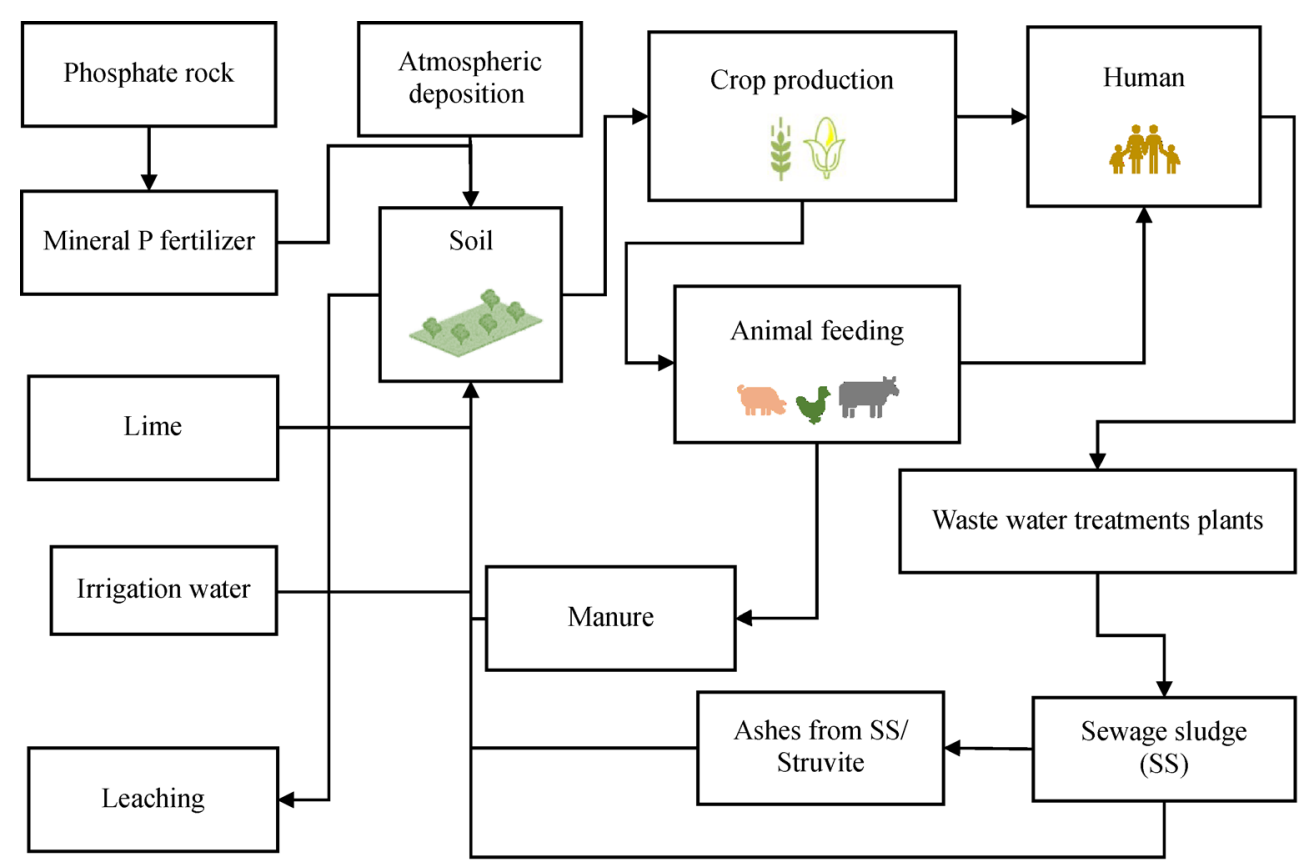

Fig. 1 General scheme of cadmium balance in an air-soil-crop system.

regardless of the suitability of the $\mathrm{pH}$ for mobilization by simultaneous competition with other metallic cations $\left(\mathrm{Ca}^{2+}, \mathrm{Mg}^{2+}, \mathrm{Zn}^{2+}\right)$ and hydrogen ions ${ }^{[34]}$.

Other physicochemical characteristics of soil, such as the high organic matter content in arable soils (for instance crop residues or input of farmyard manure) may form insoluble organic complexes with cadmium, diminishing its phytoavailability and increasing crop yield ${ }^{[20,26,35,36]}$.

In general, the processes of sorption-desorption, precipitation, and complexation reactions control the retention of metals in soils. The sorption-desorption equilibrium is the predominant process if heavy metals (such as $\mathrm{Cd}$ ) are present at a low concentration. In contrast, when heavy metal concentrations are relatively high, or the $\mathrm{pH}$ is low, the precipitation-dissolution reactions are likely to regulate availability of heavy metal in the soil solutions ${ }^{[5,31]}$.

In addition, cadmium behavior in acidic soils can be controlled by the amount of soluble organic matter. In alkaline soils, however, cadmium mobility is dominated by precipitation processes involving phosphates and carbonates $^{[17]}$.

The biotic factors influencing cadmium bioavailability include organic acids in the rhizosphere, which can form complexes with cadmium, facilitating plant uptake ${ }^{[27]}$. Further biotic factors are the microorganisms. For example, mycorrhizal fungi can decrease cadmium phytoavailability by adsorbing cadmium in their hyphae, and bacteria can take up metallic cations and release them in a less mobile form ${ }^{[27]}$. However, according to Vig et al. ${ }^{[37]}$, many studies regarding plant-microbe-metal interactions are based on soils amended with sewage sludge (SS) or on polluted sites after bioremediation. In such cases, high concentrations of cadmium, as well as other heavy metals and organic pollutants, are employed. Furthermore, the role of microbes is focused on augmenting tolerance to heavy metals in plants or reducing cadmium uptake by plants ${ }^{[37]}$. In another review related to soil microorganisms, Wyszkowska et al. ${ }^{[38]}$ point out that cadmium and other heavy metals can affect the microbial community, especially bacteria, by damaging cellular structure (protein or lipid bonding structures), denaturalization of proteins or affecting enzyme activity, and thereby, influence the microbial population and its interactions with plants.

\subsection{Cadmium and fertilizers}

The fertilizer type, the fertilization rate, the quantity per application, crop rotation, crop residues management and liming, along with the plant species and genotype, as well as changes in $\mathrm{pH}$ and plant growth, can all affect the cadmium concentration and availability in soils ${ }^{[20,26]}$. To illustrate this, chloride ions (e.g., from $\mathrm{KCl}$ fertilizers) may form soluble $\mathrm{Cd}-\mathrm{Cl}$ complexes, reducing cadmium sorption in soils and thus increasing the $\mathrm{Cd}$ mobilization and bioavailability ${ }^{[31,35]}$.

The combination of high $\mathrm{pH}$ and high fertilization rates with nitrate compounds, such as $\mathrm{Ca}\left(\mathrm{NO}_{3}\right)_{2}$, can enhance the cadmium concentration in soil solution, since calcium in solution competes with $\mathrm{Cd}^{2+}$ for adsorption by soil particles, thus increasing cadmium phytoavailability ${ }^{[32]}$.

Mineral $\mathrm{P}$ fertilizers are considered the main input source of cadmium in arable soils in Europe ${ }^{[39]}$. The cadmium comes from the raw materials used to produce 
the fertilizers, i.e., PR, which is often sourced from materials of sedimentary (with higher $\mathrm{Cd}$ concentration), rather than igneous origin (with lower $\mathrm{Cd}$ concentration). Unfortunately, only $13 \%$ of the global P sources is found in igneous $\operatorname{rock}^{[3,5,31]}$. Dependent on their origin, the cadmium concentrations in PR range from 0.10 to $60.00 \mathrm{mg} \cdot \mathrm{kg}^{-1}$, with the highest values found in PR from North Africa $\left(\sim 60.00 \mathrm{mg} \cdot \mathrm{kg}^{-1}\right)^{[40]}$. However, other studies have found cadmium concentrations above $500.00 \mathrm{mg} \cdot \mathrm{kg}^{-1}$ in PR from Morocco (Table 2) ${ }^{[14]}$.

In Europe cadmium concentrations in $\mathrm{P}$ fertilizers generally range from trace amounts to $300.00 \mathrm{mg} \cdot \mathrm{kg}^{-1}$, with an average of $7.40 \mathrm{mg} \cdot \mathrm{kg}^{-1[50]}$, and $36.00 \mathrm{mg} \mathrm{Cd}$ per $\mathrm{kg} \mathrm{P}_{2} \mathrm{O}_{5}$ considering the phosphate content ${ }^{[51]}$. The current permitted limit for cadmium in fertilizers in Germany is $50.00 \mathrm{mg} \cdot \mathrm{kg}^{-1} \mathrm{P}_{2} \mathrm{O}_{5}$ according to the German Fertilizer Ordinance ${ }^{[48]}$. Nevertheless, P fertilizers including PR, SP and TSP might exceed this value ${ }^{[14,40,48]}$.

$\mathrm{P}$ fertilizers containing ammonium, such as MAP and DAP, can temporally acidify soils as a consequence of the natural process of nitrification, thereby, releasing hydrogen ions $^{[5,31,32]}$. However, the acidification of soils caused by nitrate is only relevant when this is lost by leaching ${ }^{[52]}$.

$$
\mathrm{NH}_{2} \mathrm{H}_{2} \mathrm{PO}_{4} \rightarrow \mathrm{NH}_{4}^{+}+\mathrm{H}_{2} \mathrm{PO}_{4}^{-}
$$

$\mathrm{NH}_{4}^{+} \rightarrow$ conversion of ammonia to nitrate $\rightarrow \mathrm{NO}_{3}^{-}$

$+2 \mathrm{H}^{+} \rightarrow$ decreased $\mathrm{pH}$ and soil acidification

Another effect of ammonium fertilizer may be rhizosphere acidification when ammonium is taken up directly by the plant root, which may compensate this cation uptake by proton release. If ammonia is taken up, the proton release by conversion of ammonium to ammonia also acidifies the rhizosphere. In the case of neutral or alkaline soil solution $\mathrm{pH}$, both these variants mobilize phosphate and cadmium in the rhizosphere.

In contrast, $\mathrm{P}$ fertilizers, such as TSP and PR, can induce changes in $\mathrm{pH}$ and cadmium allocation into less available compartments after several applications ${ }^{[30,53]}$. These fertilizers can enhance the formation of insoluble cadmium-phosphate compounds, e.g., $\mathrm{Cd}_{3} \mathrm{PO}_{4}$, in soils, thus immobilizing cadmium and reducing plant uptake ${ }^{[36]}$, due to the shift in soluble-exchangeable $\mathrm{Cd}$ distribution toward more stable bound phosphate forms ${ }^{[5,32,54]}$.

\subsection{Cadmium in plants}

Cadmium can have detrimental effects on enzyme activity in plants, leading to lower photosynthesis. As a result, plant growth and development including germination, root elongation, and leaf expansion can be affected by cadmium $^{[17,55,56]}$. Under higher concentrations in soils, this metal can also produce phytotoxicity symptoms such as chlorosis, and reduced vigor and performance (for instance, water and nutrient uptake $)^{[16,56,57]}$. Reduced growth and proliferation is also a consequence of the additional $\mathrm{C}$ skeletons required for defense and repair, which usually causes the size of the most tolerant plants to be very small (e.g., hyperaccumulators such as

Table 2 Cadmium concentrations $\left(\mathrm{mg} \cdot \mathrm{kg}^{-1}\right)$ in inorganic and organic $\mathrm{P}$ fertilizers from different countries

\begin{tabular}{|c|c|c|c|c|c|c|c|}
\hline $\begin{array}{l}\text { Inorganic P ferti- } \\
\text { lizers }\end{array}$ & China & Brazil (sold) & Germany (sold) & Morocco & Russia & South Africa & USA \\
\hline \multirow[t]{4}{*}{$\overline{\mathrm{PR}}$} & $5.00^{[3]]}$ & $20.00^{[4 T]}$ & $19.00^{\mathrm{b}[42]}$ & $30.00-60.00^{[40]}$ & $0.25^{\mathrm{a}[39]}$ & $1.00^{[20]}$ & $60.00-340.00^{[3]]}$ \\
\hline & $<2.00^{[20]}$ & - & - & $12.00-38.00^{[20,31]}$ & $1.00^{[20]}$ & - & $6.00-92.00^{[20]}$ \\
\hline & $4.48^{\mathrm{a}[43]}$ & - & - & $46.00-120.00^{\mathrm{a}[39]}$ & $0.15^{[14]}$ & - & $1.45-199.00^{[14]}$ \\
\hline & $2.60^{\mathrm{b}[28]}$ & - & - & $507.00^{[14]}$ & - & - & - \\
\hline \multirow[t]{2}{*}{ DAP } & $5.10^{\mathrm{a}[39]}$ & - & $28.10^{\mathrm{a}[44]}$ & $29.50-68.00^{\mathrm{a}[39]}$ & $2.10^{\mathrm{a}[39]}$ & $2.20^{\mathrm{a}[39]}$ & $18.20-185.40^{[39]}$ \\
\hline & $2.20^{[45]}$ & - & $61.00^{\mathrm{a}[44]}$ & $9.36^{[45]}$ & $0.84^{[46]}$ & - & - \\
\hline \multirow[t]{2}{*}{ MAP } & $5.30^{\mathrm{a}[39]}$ & $17.12^{[41]}$ & - & $30.60-70.60^{\mathrm{a}[39]}$ & $2.20^{\mathrm{a}[39]}$ & $2.20^{\mathrm{a}[39]}$ & $18.80-192.40^{\mathrm{a}[39]}$ \\
\hline & - & - & - & - & $0.14^{[45]}$ & - & $50.92^{[45]}$ \\
\hline \multirow[t]{2}{*}{ NPK } & $0.60-1.51^{[45]}$ & $5.80^{[41]}$ & $15.80^{\mathrm{b}[47]}$ & $0.80-11.45^{[45]}$ & $3.23-3.66^{[45]}$ & - & - \\
\hline & - & - & $2.30^{[48]}$ & - & - & - & - \\
\hline PK & - & - & $55.60^{\mathrm{b}[47]}$ & - & - & - & - \\
\hline SP & $0.22^{\mathrm{b}[49]}$ & $8.50^{[41]}$ & $34.00^{[48]}$ & - & - & - & - \\
\hline \multirow[t]{4}{*}{ TSP } & - & - & $24.40^{[48]}$ & $31.50-72.70^{\mathrm{a}[39]}$ & $2.30^{\mathrm{a}[39]}$ & $2.30^{\mathrm{a}[39]}$ & $13.30-198.10^{\mathrm{a}[39]}$ \\
\hline & - & - & $62.00^{\mathrm{b}[42]}$ & - & - & - & - \\
\hline & - & - & $36.70-73.10^{\mathrm{b}[47]}$ & - & - & - & - \\
\hline & - & - & $28.10^{\mathrm{b}[44]}$ & - & - & - & - \\
\hline
\end{tabular}

Note: ${ }^{\mathrm{a}}$ Given in $\mathrm{mg} \cdot \mathrm{kg}^{-1} \mathrm{P}_{2} \mathrm{O}_{5} ;{ }^{\mathrm{b}}$ given in $\mathrm{mg} \cdot \mathrm{kg}^{-1}$ dry mass. PR, phosphate rock; DAP, diammonium; MAP, monoammonium; NPK, nitrogen, phosphorus, potassium; SP, superphosphate; TSP, triple superphosphate. 
Arabidopsis halleri $\left.{ }^{[58]}\right)$. Therefore, in agricultural production cadmium can be responsible for damage to crop, decreasing yield and protein content in seeds ${ }^{[55,56]}$.

Plants have developed resistance mechanisms against heavy metal pollution, and some species are hyperaccumulators of certain heavy metals. Even in nonaccumulating species, such as maize, responses can be detected. For example, when this crop is grown under cadmium presence, phytochelatins (Cd binding polypeptides) are released as a detoxification response to avoid cadmium binding to important enzymes or proteins ${ }^{[26,59]}$. Another reaction is the storage of cadmium binding peptides in the vacuole, removing the cadmium from essential and sensitive metabolic activities ${ }^{[2,55]}$.

Several environmental factors can activate an increased production of reactive oxygen species (ROS) in plants, including stress by heat, drought, air pollutants, organic chemicals or heavy metals. These compounds include hydroxyl radicals, hydrogen peroxide, singlet oxygen and, superoxide radicals, which are highly reactive products of an incomplete reduction of $\mathrm{O}_{2}$ to $\mathrm{H}_{2} \mathrm{O}$ for energy production $^{[9,32,55,60]}$. The oxidative stress triggered by high ROS concentrations impacts negatively on plant metabolism, including potential DNA damage, inhibition of enzyme activity, protein oxidation, lipid peroxidation and cell membrane damage ${ }^{[55]}$.

Thus, a further plant defense mechanism against elevated ROS production derived from heavy metal stress is the production of antioxidants. For example, some studies have detected an increased enzyme production with antioxidant activity in some maize cultivars under high cadmium concentrations, such as peroxidase, catalase, ascorbate peroxidase and superoxide dismutase ${ }^{[60]}$.

\section{Cadmium balance in arable soil}

The cadmium balance in surface soils as well as the bioaccumulation along the food chain involving crop production, are determined by the inputs and the outputs in arable land. Currently, the main cadmium input into European arable soils derives from mineral $\mathrm{P}$ fertilizers $^{[13,15,61]}$. Nonetheless, other cadmium contributions from animal manure, SS, lime, and atmospheric deposition also need to be considered (Table 3$)^{[31,39,70]}$.

For atmospheric deposition, cadmium can be present in the air as particulate matter, facilitating its mobility through the atmosphere and to other parts of the ecosphere ${ }^{[17]}$. However, this input has been reduced since 2002 in European countries through environmental policies ${ }^{[70]}$, while in China atmospheric deposition still has a larger cadmium contribution compared to $\mathrm{P}$ fertilizers $(\text { Table } 3)^{[5,71]}$.

Another important source of cadmium inputs to the soil are recycled $\mathrm{P}$ fertilizers. Due to the decline of PR reservoirs $^{[1]}$ and the increase of organic farming, the
Table 3 Atmospheric cadmium deposition $\left(\mathrm{g} \cdot \mathrm{ha}^{-1} \cdot \mathrm{yr}^{-1}\right)$ in different regions of China

\begin{tabular}{lcc}
\hline Location in China & Cadmium deposition & Reference \\
\hline Heilongjiang, Northeast & 1.46 & {$[62]$} \\
Mongolian Plateau, Northwest & 1.04 & {$[63]$} \\
Beijing, North China & 4.75 & {$[64]$} \\
Tianjin, North China & 5.30 & {$[64]$} \\
Hebei, North China & 5.57 & {$[64]$} \\
Henan, North China & 4.93 & {$[65]$} \\
Shanxi, North China & 2.04 & {$[65]$} \\
Fujian, Southeast & 0.91 & {$[65]$} \\
Lianyuan, Southeast & 17.00 & {$[66]$} \\
Shenzhen, Southeast & 7.42 & {$[66]$} \\
Guizhou, Southwest & 2.01 & {$[65]$} \\
Jiaozhou Bay, Central Yellow Sea & 1.30 & {$[67]$} \\
Daya Bay, South China Sea & 1.60 & {$[68]$} \\
East China Sea & 1.78 & {$[69]$} \\
Southern Yellow Sea & 1.80 & {$[69]$} \\
\hline
\end{tabular}

development and use of non-mineral fertilizers had intensified $^{[42]}$. These fertilizers include animal manure, dewatered SS, chemical and thermally treated SS and anaerobically digested wastes ${ }^{[42]}$.

Manure and SS, which offer a large number of benefits to agricultural soils, are also important for the cadmium pathway through the $\mathrm{P}$ cycle in crop production, since cadmium is still found in these fertilizers, especially in regions of China (Table 4). Cadmium concentrations in manure usually differ according to the animal origin, with higher amounts in swine manure regardless of the region $^{[44,51,74]}$. As a consequence of its nature, the nutrient concentration in manure is lower and more variable compared to mineral $\mathrm{P}$ fertilizer, leading to a higher field application rate ${ }^{[5]}$, and thereby, a higher cadmium input rates. For SS in Germany, the cadmium concentration in dewatered and stabilized SS should not exceed $1.00 \mathrm{mg} \cdot \mathrm{kg}^{-1[77]}$. Due to this reasonably low cadmium concentration in SS and the controlled application rate ${ }^{[78]}$, the estimated input through SS to arable land in Europe is relatively low ${ }^{[70]}$.

Another cadmium input to soils is the addition of lime, given that it can contain cadmium as an impurity. Usually liming of soils increases $\mathrm{pH}$ and reduces cadmium availability in acidic soils, thus the uptake by plants is reduced $^{[26,32,79-81]}$. Several studies have found that $50 \%-$ $70 \%$ less cadmium accumulates in maize and some vegetables (amaranth, cabbage, and lettuce), most likely due to the supply of calcium from lime and its absorption competition with cadmium ${ }^{[80-82]}$. However, this lime addition might not diminish cadmium uptake in alkaline soils, under deeper rooting or due to the antagonism with 
Table 4 Cadmium concentrations $\left(\mathrm{mg} \cdot \mathrm{kg}^{-1}\right)$ in organic P fertilizers from China, European region and Germany

\begin{tabular}{lccc}
\hline Organic P fertilizers & China & Europe & Germany \\
\hline Manure & $0.67^{\mathrm{a}[72]}$ & $0.20^{[70]}$ & $0.30^{\mathrm{a}[44]}$ \\
Swine manure & $1.30^{[73]}$ & - & - \\
& $12.05^{[74]}$ & $0.46^{[70]}$ & $0.74^{[44]}$ \\
Cattle manure & $0.64-21.02^{[75]}$ & - & - \\
& $0.92^{[73]}$ & - & $0.43^{\mathrm{a}[44]}$ \\
Poultry manure & $5.61^{[76]}$ & - & $0.80^{[42]}$ \\
& $1.48^{[73]}$ & - & $0.25^{\mathrm{a}[44]}$ \\
Sewage sludge & $15.38^{[74]}$ & $1.80^{[70]}$ & - \\
& $1.65^{[77]}$ & $0.30-5.10^{[77]}$ & $1.00^{\mathrm{a}[42,77]}$ \\
\hline
\end{tabular}

Note: ${ }^{\text {a }}$ Given in $\mathrm{mg} \cdot \mathrm{kg}^{-1}$ dry mass.

$\mathrm{Ca}^{+}$in the soil solution ${ }^{[26]}$.

When calculating the cadmium outputs from the soil, crop uptake and leaching must be considered $\left(\right.$ Table 5) ${ }^{[15,44,61]}$. While crop harvest contributes to the output, leaching most likely represents a significant output from agricultural soils ${ }^{[70]}$. Several factors influence cadmium leaching, including the sorption-desorption processes, which, as specified in Section 2.2, regulate the cadmium retention in soils. One of the most important sorption types is non-specific sorption. This occurs when cadmium is weakly bound to negatively charged surfaces by electrostatic attraction, and can be easily replaced by other ions (exchangeable) and predisposed to leaching and bioavailability ${ }^{[31,91]}$. Another influencing factor is the $\mathrm{pH}$, which could cause increased leaching when the value is lower, while higher $\mathrm{pH}$ values decrease this variable ${ }^{[92]}$. For instance, data obtained by He et al. ${ }^{[93]}$ indicate that the cadmium quantity adsorbed in soils was higher, the more acidic these became. This is due to the likely release of hydrogen ions from adsorption sites and their replacement with cadmium ${ }^{[93]}$. Paradoxically, as mentioned before, a lower $\mathrm{pH}$ can increase the cadmium leaching to deeper layers. Furthermore, periods with elevated precipitation (water surplus or excess of precipitation) contribute to leaching to deeper layers since cadmium leaching is coupled to water leaching ${ }^{[94]}$. Other factors such as soil density, total cadmium concentration in the soil, temperature, distribution coefficient $\left(K_{D}\right)$, cation exchange capacity (CEC), which is influenced by organic matter and clay content, are known to influence cadmium leaching $^{[61,70,93,95]}$. Thus, leaching rates are usually modeled or calculated ${ }^{[15]}$. In 2014, Six and Smolders ${ }^{[70]}$ calculated a relatively high leaching rate for European soils, which represents the main output from arable soils (Table 5). This agrees with some Chinese studies, in which leaching has been found to be the main output mechanism rather than crop harvesting ${ }^{[15,87]}$. However, another recent study has indicated that the high value for leaching for European soils could be an overestimation due to the equation used $^{[61]}$ since lower rates of cadmium leaching were measured or calculated in other studies done in soils from Europe and New Zealand ${ }^{[19,94,95]}$. Furthermore, soils in Europe are usually limed ${ }^{[70]}$, which should be sufficient to buffer soil and avoid cadmium leaching.

\section{Long-term studies}

\subsection{Field studies}

One single application of fertilizer may not cause a significant accumulation of heavy metals in arable land. However, repeated fertilizer application over the long-term can result in harmful heavy metal concentrations for crops and for bioaccumulation potential in the food chain, thus representing a health risk ${ }^{[76,96,97]}$. Nevertheless, contrasting studies reviewed by Jiao et al. ${ }^{[28]}$ indicate that cadmium concentrations in soils might not be affected by $P$ fertilization addition in the long term.

Long-term studies by Gray et al. ${ }^{[96]}$ in pastures of New Zealand indicated that after 44 years of $\mathrm{P}$ mineral fertilization, an increase in total soil cadmium had occurred. The P fertilizer used (single SP) had relatively high concentrations of cadmium, ranging between 34.00 and $69.00 \mathrm{mg} \cdot \mathrm{kg}^{-1}$. However, after the long period of fertilization, a higher proportion of cadmium was in the residual soil fraction, which represents the residual and least mobile fraction from the sequential extraction method used, indicating that cadmium moves to less plantavailable forms with time ${ }^{[96]}$.

Results from other long-term fertilization experiments ( $>22$ years) suggest that animal manure could cause cadmium accumulation in soils as a consequence of the mixture of mineral and non-mineral fertilizers ${ }^{[33,97]}$. In one of these studies, cadmium concentrations were 10 to 25 times higher than prior to fertilization with manure. However, the manure decreased the uptake of cadmium by the maize crop ${ }^{[97]}$, while in other field experiments 


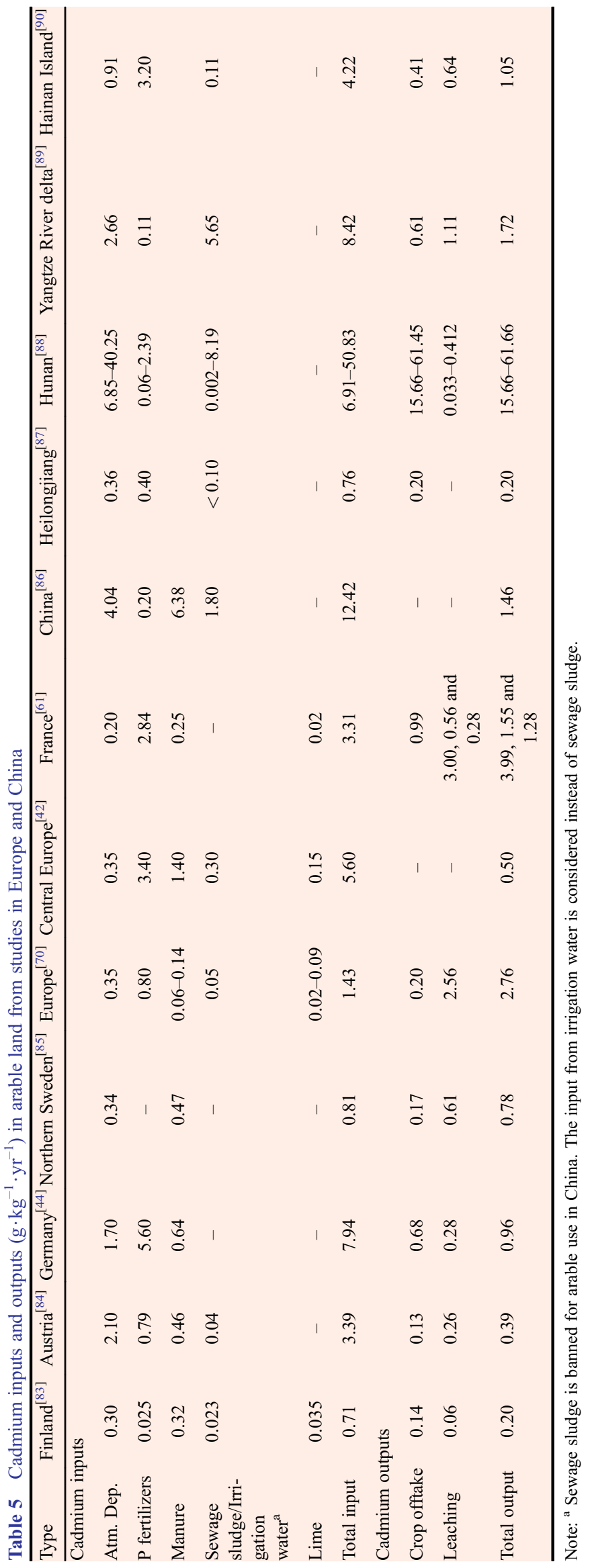


under swine manure and NPK fertilization, the plantavailable cadmium fraction in soils decreased compared to the total concentration ${ }^{[33]}$. This may be due to the formation of insoluble cadmium-complexes with organic compounds originating from the manure ${ }^{[26,35]}$. In other words, the application of amendments, namely manure and SS, does not decrease (or increase) the total cadmium concentration, but their application can reduce its bioavailability for crops ${ }^{[23]}$.

In another long-term experiment (17 years) by $\mathrm{Wu}$ et al. ${ }^{[76]}$, the application of pig manure together with mineral fertilizer (NPK) increased the total cadmium concentration in different soil types: 'black' soils, which have a higher quality humus and a moderate to high organic matter content ${ }^{[98,99]}$, and 'red' soils, which have high contents of $\mathrm{Al}$-and Fe-oxides, and a lower $\mathrm{CEC}^{[98]}$. In this long-term experiment, the cadmium bioavailability (reducible and exchangeable fractions) was determined by the soil type: the 'red' soil had a lower cadmium bioavailability and a higher residual fraction, while the 'black' soil had a higher cadmium percentage in the exchangeable and reducible fraction. This is likely due to the mineral differences between both soils. Still, for mineral $\mathrm{P}$ fertilizer, application in the form of calcium superphosphate did not result in any difference in cadmium concentration compared to the unfertilized soils ${ }^{[76]}$.

\subsection{Models and trends}

The problem of relatively high cadmium concentrations in fertilizers is not just a recent concern and several papers have approached this challenging situation in the past.

Cupit et al. ${ }^{[100]}$ studied the economic aspects, concluding that the lowest cost option for decreasing cadmium risks was to use low-cadmium phosphate rock, since taxing the fertilizers with high cadmium concentrations would impact largely on the farmer. Another suggested option was to the limit concentration gradually from $60.00 \mathrm{mg} \mathrm{Cd}$ per $\mathrm{kg} \mathrm{P}_{2} \mathrm{O}_{5}$ by 2006 to $20.00 \mathrm{mg} \mathrm{Cd}$ per $\mathrm{kg} \mathrm{P}_{2} \mathrm{O}_{5}$ by $2015^{[20,100]}$. However, a lower threshold would affect important producers and exporters ${ }^{[39,101]}$, for instance, producers from Morocco, where cadmium concentrations in PR are usually higher than $20.00 \mathrm{mg} \mathrm{Cd}$ per $\mathrm{kg}$ $\mathrm{P}_{2} \mathrm{O}_{5}{ }^{[14,39,40]}$, and in 2018 the flexible limit was still $60.00 \mathrm{mg}$ Cd per kg $\mathrm{P}_{2} \mathrm{O}_{5}{ }^{[102]}$.

In a study by Smolders and $\mathrm{Six}^{[51]}$, European soils with different $\mathrm{P}$ fertilizers concentrations (with $0,40.00,60.00$ and $80.00 \mathrm{mg} \mathrm{Cd}$ per $\mathrm{kg}_{2} \mathrm{O}_{5}$ ) were modeled. It was predicted that soil cadmium will stay constant over the long-term (100 years), even if fertilizers with the highest concentrations of cadmium were to be applied. Additionally, under low or medium fertilizer application, the cadmium concentrations in the soil will decrease in most of the scenarios after 100 years of $\mathrm{P}$ fertilizers application. This prediction was based on lower P fertilization rates, leaching rates, the $K_{D}$ models used and the strong reduction in atmospheric deposition of cadmium in European countries, compared to other mass balances done previously.

Another mass balance model, for accumulation of cadmium and other hazardous substances after 200 years of different $\mathrm{P}$ fertilizer application, was developed by Weissengruber et al. ${ }^{[42]}$. The authors assumed two different $\mathrm{pH}$ values and different rainfall scenarios to test the influence of diverse fertilizers on hazardous substances accumulation. These fertilizers included mineral fertilizers (e.g., TSP), recycled $\mathrm{P}$ fertilizers allowed in organic farming (e.g., compost), and other emerging options (e.g., treated biosolid ashes). The results indicated that there is likely to be a decline in cadmium accumulation in soils even when high cadmium concentration fertilizers are applied, which agrees with the study of Six and Smolders ${ }^{[70]}$. However, there is a probability of cadmium output by leaching and crop harvests, which is higher under TSP, PR and compost application. Recycled fertilizer had a higher probability of cadmium output than struvite or biosolids ashes, as the result of the fertilizer application rate, which is dominated by the $\mathrm{P}$ concentration in the fertilizers. In other words, if the $\mathrm{P}$ concentration is lower, such as in green compost, the application frequency will increase to meet the crop $\mathrm{P}$ demand, as will the addition of hazardous substances as a consequence. Meanwhile, if the $\mathrm{P}$ concentration is relatively high, as in struvite or biosolid ashes, the $\mathrm{P}$ fertilization rate decreases and therefore the pollutant input to soils will also decrease, despite cadmium concentration of these fertilizers being higher ${ }^{[5,15,42]}$.

In contrast to these results, Qian et al. ${ }^{[103]}$ indicated that cadmium concentrations in Chinese soils will increase, reaching the acceptable threshold for agricultural soils in 50 years. This is the result of the cadmium background concentrations in soil, the atmospheric deposition and the continuous application of animal manure to fields, which are the main heavy metal inputs to arable soils in China $^{[15,71]}$, especially from swine manure, which has higher cadmium concentrations than the current approved limit $\left(\mathrm{Cd}<3.00 \mathrm{mg} \cdot \mathrm{kg}^{-1} \mathrm{DM}\right)^{[74]}$.

Another mass balance model for actual $\mathrm{P}$ fertilizer application rates in soils in France was developed by Sterckeman et al. ${ }^{[61]}$. In their study, the authors indicated that under high leaching rates (using the equation from Six and Smolders ${ }^{[70]}$ ), the cadmium concentration in the soil would decrease in the long-term (100 years) from 0.31 to $0.29 \mathrm{mg} \cdot \mathrm{kg}^{-1}$. Meanwhile, considering a medium and low leaching rate, cadmium would increase from 0.31 to 0.35 and $0.36 \mathrm{mg} \cdot \mathrm{kg}^{-1}$, respectively. In addition, the increase of cadmium in soils under the actual $P$ rates would lead to proportionally higher crop uptake, increasing the cadmium exposure of animals and humans through dietary intake ${ }^{[61]}$.

There are numerous model studies, however, the results 
of these cadmium accumulation models can be imprecise, due to the many assumptions and generalizations that are made to simplify the complexity of reality, including social, agricultural, climatic and regional factors ${ }^{[102]}$. Moreover, the lack of consistency in the leaching rate estimates indicates that its determination in different regions and environmental variables should be a priority to eliminate further uncertainties around this factor.

\section{Conclusions and outlooks}

Cadmium input from phosphate fertilizers represents an environmental and health risk due to soil pollution, crop uptake, and bioaccumulation along the food chain. A decrease in mineral $\mathrm{P}$ fertilizer dependence, along with the use of non-polluted recycled fertilizers could alleviate the gap in the $\mathrm{P}$ cycle and the cadmium pollution of arable land, in countries such as Germany, where atmospheric deposition does not represent an important cadmium contribution to the soil. In countries like China, however, where atmospheric deposition and the manure application are the main cadmium inputs to agricultural land, environmental policies, and trace metals limits in animal waste could be used to decrease the pollution of arable land.

Future work should focus on cadmium balances in arable land, considering the soil properties (e.g., $\mathrm{pH}$ and $\mathrm{CEC}$ ), crop and soil management (e.g., liming) and therefore the potential leaching, which seems to be an important but also inconsistent output regarding cadmium balance models. The social, climatic and economic differences and circumstances among countries should also be taken into account. Furthermore, there is a lack of knowledge about the potential accumulation of cadmium from $\mathrm{P}$ fertilizers via crops in the various elements of the food chain and in the P cycle. Hopefully, an improved, highly efficient $\mathrm{P}$ input and a more closed $\mathrm{P}$ cycling can mitigate the problem of cadmium pollution, due to a higher recycling and a lower dependency on mineral $\mathrm{P}$ fertilizer from sedimentary origin, but this remains to be investigated.

\footnotetext{
Acknowledgements This review was carried out as part of the project "Adaptation of Maize-based Food-feed-energy Systems to Limited Phosphate Resources" from the German-Chinese International Research Training Group 2366. The authors gratefully acknowledge the support for this project provided by the Deutsche Forschungsgemeinschaft (DFG, German Research Foundation)-328017493/GRK 2366 and Ten-Thousand Talent Program of China (Xuejun Liu).
}

Compliance with ethics guidelines Andrea Giovanna Niño-Savala, Zhong Zhuang, Xin Ma, Andreas Fangmeier, Huafen Li, Aohan Tang, and Xuejun Liu declare that they have no conflicts of interest or financial conflicts to disclose.

This article is a review and does not contain any studies with human or animal subjects performed by any of the authors.

\section{References}

1. Childers D L, Corman J, Edwards M, Elser J J. Sustainability challenges of phosphorus and food: solutions from closing the human phosphorus cycle. Bioscience, 2011, 61(2): 117-124

2. Gupta D K, Chatterjee S, Datta S, Veer V, Walther C. Role of phosphate fertilizers in heavy metal uptake and detoxification of toxic metals. Chemosphere, 2014, 108: 134-144

3. Linderholm K, Tillman A M, Mattsson J E. Life cycle assessment of phosphorus alternatives for Swedish agriculture. Resources, Conservation and Recycling, 2012, 66: 27-39

4. Taylor M, Kim N, Smidt G, Busby C, McNally S, Robinson B, Kratz S, Schnug E. Trace element contaminants and radioactivity from phosphate fertiliser. In: Schnug E, de Kok L J, eds. Phosphorus in agriculture: $100 \%$ zero. New York: Springer Berlin Heidelberg, 2016, 22: 231-266

5. Selim H M. Phosphate in soils: interaction with micronutrients, radionuclides and heavy metals. Advances in trace elements in the environment. Boca Raton: CRC Press, 2015

6. US Geological Survey. Phosphate rock: mineral commodity summaries, 1996, 2000, 2006, 2011, 2016. Available at US Geological Survey (USGS) website on February 11, 2019

7. US Geological Survey. Phosphate rock: mineral yearbook, 1996, 2001, 2006, 2012, 2016. Available at US Geological Survey (USGS) website on February 11, 2019

8. International Fertilizer Industry Association. IFAData. Available at International Fertilizer Industry Association website on February 11,2019

9. Dikilitas M, Karakas S, Ahmad P. Chapter 13: effect of lead on plant and human DNA damages and its impact on the environment. In: Ahmad P, ed. Plant metal interaction: emerging remediation techniques. Amsterdam, Boston: Elsevier, 2016, 41-67

10. Rosemarin A, Ekane N. The governance gap surrounding phosphorus. Nutrient Cycling in Agroecosystems, 2016, 104(3): 265-279

11. Desmidt E, Ghyselbrecht K, Zhang Y, Pinoy L, van der Bruggen B, Verstraete W, Rabaey K, Meesschaert B. Global phosphorus scarcity and full-scale P-recovery techniques: a review. Critical Reviews in Environmental Science and Technology, 2015, 45(4): 336-384

12. Jasinski S M. Phosphate rock: mineral commodities summaries, 2019. Available at US Geological Surrey (USGS) website on May 14, 2019

13. Bigalke M, Ulrich A, Rehmus A, Keller A. Accumulation of cadmium and uranium in arable soils in Switzerland. Environmental pollution, 2017, 221: 85-93

14. Mar S S, Okazaki M. Investigation of Cd contents in several phosphate rocks used for the production of fertilizer. Microchemical Journal, 2012, 104: 17-21

15. Shi T, Ma J, Wu X, Ju T, Lin X, Zhang Y, Li X, Gong Y, Hou H, Zhao L, Wu F. Inventories of heavy metal inputs and outputs to and from agricultural soils: a review. Ecotoxicology and Environmental Safety, 2018, 164: 118-124

16. Kabata-Pendias A, Pendias H. Trace elements in soils and plants. 3rd ed. Boca Raton: CRC Press, 2001 
17. Kabata-Pendias A, Szteke B. Chapter 5: trace elements in abiotic and biotic environments. Boca Raton: CRC Press, 2015

18. Godt J, Scheidig F, Grosse-Siestrup C, Esche V, Brandenburg P, Reich A, Groneberg D A. The toxicity of cadmium and resulting hazards for human health. Journal of Occupational Medicine and Toxicology, 2006, 1(1): 22

19. Gray C W, McLaren R G, Roberts A H C. Cadmium leaching from some New Zealand pasture soils. European Journal of Soil Science, 2003, 54(1): 159-166

20. Roberts T L. Cadmium and phosphorous fertilizers: the issues and the science. Procedia Engineering, 2014, 83: 52-59

21. World Health Organization/Food and Agriculture Organization of the United Nations. Joint FAO/WHO expert committee on food additives: summary report of the seventy-third meeting of JECFA, 2010

22. Phillips C J C, Prankel S H. Cadmium and the welfare of animals. Encyclopedia of Environmental Health, Reference Module. Earth Systems and Environmental Sciences, 2011, 451-455

23. Khan M A, Khan S, Khan A, Alam M. Soil contamination with cadmium, consequences and remediation using organic amendments. Science of the Total Environment, 2017, 601-602: 15911605

24. Yu G, Zheng W, Wang W, Dai F, Zhang Z, Yuan Y, Wang Q. Health risk assessment of Chinese consumers to cadmium via dietary intake. Journal of Trace Elements in Medicine and Biology: Organ of the Society for Minerals and Trace Elements (GMS), 2017, 44: 137-145

25. Zhang X, Chen D, Zhong T, Zhang X, Cheng M, Li X. Assessment of cadmium (Cd) concentration in arable soil in China. Environmental Science and Pollution Research International, 2015, 22(7): 4932-4941

26. Grant C A, Buckley W T, Bailey L D, Selles F. Cadmium accumulation in crops. Canadian Journal of Plant Science, 1998, 78(1): $1-17$

27. Kumar R, Mishra R K, Mishra V, Qidwai A, Pandey A, Shukla S K, Pandey M, Pathak A, Dikshit A. Detoxification and tolerance of heavy metals in plants. In: Ahmad P, ed. Plant metal interaction: emerging remediation techniques. Amsterdam, Boston: Elsevier, 2016, 335-359

28. Jiao W, Chen W, Chang A C, Page A L. Environmental risks of trace elements associated with long-term phosphate fertilizers applications: a review. Environmental Pollution, 2012, 168: 44-53

29. Gray C W, McLaren R G, Roberts A H C, Condron L M. Effect of soil $\mathrm{pH}$ on cadmium phytoavailability in some New Zealand soils. New Zealand Journal of Crop and Horticultural Science, 1999, 27 (2): 169-179

30. Lambert R, Grant C, Sauvé S. Cadmium and zinc in soil solution extracts following the application of phosphate fertilizers. Science of the Total Environment, 2007, 378(3): 293-305

31. Mclaughlin M J, Tiller K G, Naidu R, Stevens D P. Review: the behaviour and environmental impact of contaminants in fertilizers. Australian Journal of Soil Research, 1996, 34(1): 1

32. Sarwar N, Malhi S S, Zia M H, Naeem A, Bibi S, Farid G. Role of mineral nutrition in minimizing cadmium accumulation by plants. Journal of the Science of Food and Agriculture, 2010, 90(6): 925937
33. Guan D X, Sun F S, Yu G H, Polizzotto M L, Liu Y G. Total and available metal concentrations in soils from six long-term fertilization sites across China. Environmental Science and Pollution Research International, 2018, 25(31): 31666-31678

34. Hatch D J, Jones L H P, Burau R G. The effect of $\mathrm{pH}$ on the uptake of cadmium by four plant species grown in flowing solution culture. Plant and Soil, 1988, 105(1): 121-126

35. Grant C A, Sheppard S C. Fertilizer impacts on cadmium availability in agricultural soils and crops. Human and Ecological Risk Assessment, 2008, 14(2): 210-228

36. Wang Q, Zhang J, Zhao B, Xin X, Zhang C, Zhang H. The influence of long-term fertilization on cadmium (Cd) accumulation in soil and its uptake by crops. Environmental Science and Pollution Research International, 2014, 21(17): 10377-10385

37. Vig K, Megharaj M, Sethunathan N, Naidu R. Bioavailability and toxicity of cadmium to microorganisms and their activities in soil: a review. Advances in Environmental Research, 2003, 8(1): 121-135

38. Wyszkowska J, Kucharski J, Kucharski M, Borowik A. Effect of cadmium, copper and zinc on plants, soil microorganisms and soil enzymes. Journal of Elementology, 2013, 4: 769-796

39. European Commission. Limits for cadmium in phosphate fertilisers: proposal for a regulation of the European Parliament and of the council laying down rules on the making available on the market of CE marked fertilising products and amending Regulations (EC) No 1069/2009 and (EC) No 1107/2009, Brussels, 2016. Available at European Commission website on October 24, 2018

40. Aydin I, Aydin F, Saydut A, Bakirdere E G, Hamamci C. Hazardous metal geochemistry of sedimentary phosphate rock used for fertilizer. Microchemical Journal, 2010, 96(2): 247-251

41. Vieira da Silva F B, Araújo do Nascimento C W, Muniz Araújo P R. Environmental risk of trace elements in P-containing fertilizers marketed in Brazil. Journal of Soil Science and Plant Nutrition, 2017, 17(3): 635-647

42. Weissengruber L, Möller K, Puschenreiter M, Friedel J K. Longterm soil accumulation of potentially toxic elements and selected organic pollutants through application of recycled phosphorus fertilizers for organic farming conditions. Nutrient Cycling in Agroecosystems, 2018, 110(3): 427-449

43. Qingqing H, Xing L, Qian Z. Evaluating the environmental risk and the bioavailability of $\mathrm{Cd}$ in phosphorus fertilizers. Environmental Science \& Technology, 2016, 39(2): 156-161 (in Chinese)

44. Schütze G, Becker R, Däammgen U, Nagel H D, Schlutow A, Weigel H J. Risk assessment of cadmium exposure to humans and the environment as a result of the use of cadmium-containing fertilizers. Landbauforschung Völkenrode, 2003, 2/3(53) (in German)

45. Lugon-Moulin N, Ryan L, Donini P, Rossi L. Cadmium content of phosphate fertilizers used for tobacco production. Agronomy for Sustainable Development, 2006, 26(3): 151-155

46. Bošković-Rakočević L, Pavlović R, Đurić M. Effect of phosphorus fertilizers on yield and cadmium content of potato tubers. Acta Agriculturae Serbica, 2017, 22(44): 37-46

47. Dittrich B, Klose R. Determination and evaluation of heavy metals in fertilizers, soil additives and crop substrates. Available at Fachrepositorium Lebenswissenschaften (Field Repositorium of 
Life Sciences) website on May 24, 2019 (in German)

48. Kratz S, Schick J, Schnug E. Trace elements in rock phosphates and $\mathrm{P}$ containing mineral and organo-mineral fertilizers sold in Germany. Science of the Total Environment, 2016, 542(Pt B): 1013-1019

49. Huang Q, Yu Y, Wan Y, Wang Q, Luo Z, Qiao Y, Su D, Li H. Effects of continuous fertilization on bioavailability and fractionation of cadmium in soil and its uptake by rice (Oryza sativa L.). Journal of Environmental Management, 2018, 215: 13-21

50. Nziguheba G, Smolders E. Inputs of trace elements in agricultural soils via phosphate fertilizers in European countries. Science of the Total Environment, 2008, 390(1): 53-57

51. Smolders E, Six L. Revisiting and updating the effect of revisiting and updating the effect of phosphate fertilizers to cadmium accumulation in European agricultural soil, 2013, Available at European Commission/Scientific Committee on Health and Environmetal Risks website on October 10, 2018

52. Bolan N, Hedley M, White R. Processes of soil acidification during nitrogen cycling with emphasis on legume based pastures. Plant and Soil, 1991, 134(1): 53-63

53. Kassir L N, Darwish T, Shaban A, Olivier G, Ouaini N. Mobility and bioavailability of selected trace elements in Mediterranean red soil amended with phosphate fertilizers: experimental study. Geoderma, 2012, 189-190: 357-368

54. Lee H H, Owens V N, Park S, Kim J, Hong C O. Adsorption and precipitation of cadmium affected by chemical form and addition rate of phosphate in soils having different levels of cadmium. Chemosphere, 2018, 206: 369-375

55. Hameed A, Rasool S, Azooz M M, Hossain M A, Ahanger M A, Ahmad P. Heavy metal stress: responses and signaling. In: Ahmad $\mathrm{P}$, ed. Plant metal interaction: emerging remediation techniques, Amsterdam, Boston: Elsevier, 2016, 557-583

56. He S, Yang X, He Z, Baligar V C. Morphological and physiological responses of plants to cadmium toxicity: a review. Pedosphere, 2017, 27(3): 421-438

57. Lux A, Martinka M, Vaculík M, White P J. Root responses to cadmium in the rhizosphere: a review. Journal of Experimental Botany, 2011, 62(1): 21-37

58. Zhao F J, Jiang R F, Dunham S J, McGrath S P. Cadmium uptake, translocation and tolerance in the hyperaccumulator Arabidopsis halleri. New Phytologist, 2006, 172(4): 646-654

59. Keltjens W G, van Beusichem M L. Phytochelatins as biomarkers for heavy metal stress in maize (Zea mays L.) and wheat (Triticum aestivum L.): combined effects of copper and cadmium. Plant and Soil, 1998, 203(1): 119-126

60. Anjum S A, Tanveer M, Hussain S, Bao M, Wang L, Khan I, Ullah E, Tung S A, Samad R A, Shahzad B. Cadmium toxicity in maize (Zea mays L.): consequences on antioxidative systems, reactive oxygen species and cadmium accumulation. Environmental Science and Pollution Research International, 2015, 22(21): 17022-17030

61. Sterckeman T, Gossiaux L, Guimont S, Sirguey C, Lin Z. Cadmium mass balance in French soils under annual crops: scenarios for the next century. Science of the Total Environment, 2018, 639: 1440-1452

62. Deng C, Sun G, Yang W, Li Z, Zhang L, Ding J, Fu A. Analysis of the deposition flux and source of heavy metal elements in atmospheric dustfall in Gannan county, Heilongjiang Province. Earth Environ, 2012, 40(3): 342-348 (in Chinese)

63. Wan D, Song L, Mao X, Yang J, Jin Z, Yang H. One-century sediment records of heavy metal pollution on the southeast Mongolian Plateau: implications for air pollution trend in China. Chemosphere, 2019, 220: 539-545

64. Pan Y P, Wang Y S. Atmospheric wet and dry deposition of trace elements at 10 sites in Northern China. Atmospheric Chemistry and Physics, 2015, 15(2): 951-972

65. Zhang Y, Zhang S, Zhu F, Wang A, Dai H, Cheng S, Wang J, Tang L. Atmospheric heavy metal deposition in agro-ecosystems in China. Environmental Science and Pollution Research International, 2018, 25(6): 5822-5831

66. Liang J, Feng C, Zeng G, Zhong M, Gao X, Li X, He X, Li X, Fang $\mathrm{Y}$, Mo D. Atmospheric deposition of mercury and cadmium impacts on topsoil in a typical coal mine city, Lianyuan, China. Chemosphere, 2017, 189: 198-205

67. Xing J, Song J, Yuan H, Wang Q, Li X, Li N, Duan L, Qu B. Atmospheric wet deposition of dissolved trace elements to Jiaozhou Bay, North China: fluxes, sources and potential effects on aquatic environments. Chemosphere, 2017, 174: 428-436

68. Wu Y, Zhang J, Ni Z, Liu S, Jiang Z, Huang X. Atmospheric deposition of trace elements to Daya Bay, South China Sea: fluxes and sources. Marine Pollution Bulletin, 2018, 127: 672-683

69. Changling L, Guosen Z, Hongbo R, Jing Z. Distribution of heavy metals and nutrients in rainwater in coastal regions between the southern Yellow Sea and East China Sea. Chinese Journal of Oceanology and Limnology, 2005, 23(2): 230-237

70. Six L, Smolders E. Future trends in soil cadmium concentration under current cadmium fluxes to European agricultural soils. Science of the Total Environment, 2014, 485-486: 319-328

71. Shi T, Ma J, Wu F, Ju T, Gong Y, Zhang Y, Wu X, Hou H, Zhao L, Shi H. Mass balance-based inventory of heavy metals inputs to and outputs from agricultural soils in Zhejiang Province, China. Science of the Total Environment, 2019, 649: 1269-1280

72. Yang X, Li Q, Tang Z, Zhang W, Yu G, Shen Q, Zhao F J. Heavy metal concentrations and arsenic speciation in animal manure composts in China. Waste Management, 2017, 64: 333-339

73. Wang H, Dong Y, Yang Y, Toor G S, Zhang X. Changes in heavy metal contents in animal feeds and manures in an intensive animal production region of China. Journal of Environmental Sciences, 2013, 25(12): 2435-2442

74. Li Y X, Xiong X, Lin C Y, Zhang F S, Wei L, Wei H. Cadmium in animal production and its potential hazard on Beijing and Fuxin farmlands. Journal of Hazardous Materials, 2010, 177(1-3): 475480

75. Xu Y G, Yu W T, Ma Q, Zhou H Z. Potential risk of cadmium in a soil-plant system as a result\&nbsp of long-term (10 years) pig manure application. Plant, Soil and Environment, 2015, 61(8): 352-357

76. Wu L, Tan C, Liu L, Zhu P, Peng C, Luo Y, Christie P. Cadmium bioavailability in surface soils receiving long-term applications of inorganic fertilizers and pig manure. Geoderma, 2012, 173-174: 224-230

77. Fijalkowski K, Rorat A, Grobelak A, Kacprzak M J. The presence 
of contaminations in sewage sludge-The current situation. Journal of Environmental Management, 2017, 203(Pt 3): 11261136

78. Wiechmann B, Dienemann C, Kabbe C, Brandt S, Vogel I, Roskosch A. Sewage sludge management in Germany, 2015. Available at Umweltbundesamt (German Environment Agency) website on November 2, 2018

79. Tlustos P, Szakova J, Korinek K, Pavlikova D, Hanc A, Balik J. The effect of liming on cadmium, lead, and zinc uptake reduction by spring wheat grown in contaminated soil. Plant, Soil and Environment, 2006, 52(1): 16-24

80. Guo X F, Wei Z B, We Q T, Qiu J R, Zhou J L. Cadmium and zinc accumulation in maize grain as affected by cultivars and chemical fixation amendments. Pedosphere, 2011, 21(5): 650-656

81. Rochayati S, Verloo M, Du Laing G. Availability of cadmium and zinc as affected by the use of reactive phosphate rock, lime, and chicken manure on an Indonesian acidic upland soil under field conditions. Communications in Soil Science and Plant Analysis, 2010, 41(16): 1986-2003

82. Tan W N, Li Z A, Qiu J, Zou B, Li N Y, Zhuang P, Wang G. Lime and phosphate could reduce cadmium uptake by five vegetables commonly grown in South China. Pedosphere, 2011, 21(2): 223229

83. Louekari K. Cadmium in fertilizers risks to human health and the environment. Publications, 4/2000. Helsinki: Ministry of Agriculture and Forestry, 2000

84. Zethner G, Goodchild R. A risk assessment for cadmium in Austria based on the recommendations of ERM. Final report from the Federal Environment Agency-Austria, 2000

85. Bengtsson H, Alvenäs G, Nilsson S I, Hultman B, Öborn I. Cadmium, copper and zinc leaching and surface run-off losses at the Öjebyn farm in Northern Sweden-Temporal and spatial variation. Agriculture, Ecosystems \& Environment, 2006, 113(14): $120-138$

86. Luo L, Ma Y, Zhang S, Wei D, Zhu Y G. An inventory of trace element inputs to agricultural soils in China. Journal of Environmental Management, 2009, 90(8): 2524-2530

87. Xia X, Yang Z, Cui Y, Li Y, Hou Q, Yu T. Soil heavy metal concentrations and their typical input and output fluxes on the southern Song-nen Plain, Heilongjiang Province, China. Journal of Geochemical Exploration, 2014, 139: 85-96

88. Yi K, Fan W, Chen J, Jiang S, Huang S, Peng L, Zeng Q, Luo S. Annual input and output fluxes of heavy metals to paddy fields in four types of contaminated areas in Hunan Province, China. Science of the Total Environment, 2018, 634: 67-76

89. Hou Q, Yang Z, Ji J, Yu T, Chen G, Li J, Xia X, Zhang M, Yuan X. Annual net input fluxes of heavy metals of the agro-ecosystem in the Yangtze River delta, China. Journal of Geochemical Exploration, 2014, 139: 68-84

90. Jiang W, Hou Q, Yang Z, Yu T, Zhong C, Yang Y, Fu Y. Annual input fluxes of heavy metals in agricultural soil of Hainan Island, China. Environmental Science and Pollution Research International, 2014, 21(13): 7876-7885

91. Loganathan P, Vigneswaran S, Kandasamy J, Naidu R. Cadmium sorption and desorption in soils: a review. Critical Reviews in Environmental Science and Technology, 2012, 42(5): 489-533

92. Houben D, Evrard L, Sonnet P. Mobility, bioavailability and $\mathrm{pH}-$ dependent leaching of cadmium, zinc and lead in a contaminated soil amended with biochar. Chemosphere, 2013, 92(11): 14501457

93. He Z L, Xu H P, Zhu Y M, Yang X E, Chen G C. Adsorptiondesorption characteristics of cadmium in variable charge soils. Journal of Environmental Science and Health, Part A: Toxic/ Hazardous Substances and Environmental Engineering, 2005, 40 (4): $805-822$

94. Legind C N, Rein A, Serre J, Brochier V, Haudin C S, Cambier P, Houot S, Trapp S. Simultaneous simulations of uptake in plants and leaching to groundwater of cadmium and lead for arable land amended with compost or farmyard manure. PLoS One, 2012, 7 (10): e47002

95. Römkens P F A M, Salomons W. Cd, Cu and $\mathrm{Zn}$ solubility in arable forest soils: consequences of land use changes for metal mobility and risk assessment. Soil Science, 1998, 163: 859-871

96. Gray C W, McLaren R G, Roberts A H C, Condron L M. The effect of long-term phosphatic fertiliser applications on the amounts and forms of cadmium in soils under pasture in New Zealand. Nutrient Cycling in Agroecosystems, 1999, 54(3): 267-277

97. Zhou S, Liu J, Xu M, Lv J, Sun N. Accumulation, availability, and uptake of heavy metals in a red soil after 22-year fertilization and cropping. Environmental Science and Pollution Research International, 2015, 22(19): 15154-15163

98. Delvaoux M B, Brahy V. Mineral soils conditioned by a wet (sub) tropical climate, Belgium. Available at FAO (Food and Agriculture Organization of the United Nations) website on May 21, 2019

99. Food and Agriculture Organizations of the United Nations (FAO). What is a black soil? Available at FAO website on May 21, 2019

100. Cupit M, Larsson O, de Meeûs C, Eduljee G H, Hutton M. Assessment and management of risks arising from exposure to cadmium in fertilisers-II. Science of the Total Environment, 2002, 291(1-3): 189-206

101. European Parliament. Maximum cadmium levels in fertilisers. Available at European Parliament website on January 18, 2019

102. Ulrich A E. Cadmium governance in Europe's phosphate fertilizers: not so fast? Science of the Total Environment, 2019, 650(Pt 1): 541-545

103. Qian X, Wang Z, Shen G, Chen X, Tang Z, Guo C, Gu H, Fu K. Heavy metals accumulation in soil after 4 years of continuous land application of swine manure: a field-scale monitoring and modeling estimation. Chemosphere, 2018, 210: 1029-1034 